NASA Technical Memorandum 105962

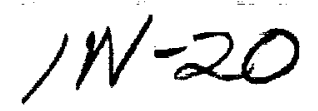

136509

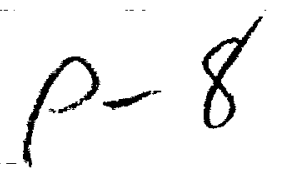

\title{
Nuclear Thermal Rocket Nozzle Testing and Evaluation Program
}

Kenneth O. Davidian and Kenneth J. Kacynski

Lewis Research Center

Cleveland, Ohio

Prepared for the

10th Symposium on Space Nuclear Power and Propulsion sponsored by the Institute for Space Nuclear Power Studies

Albuquerque, New Mexico, January 10-13, 1993

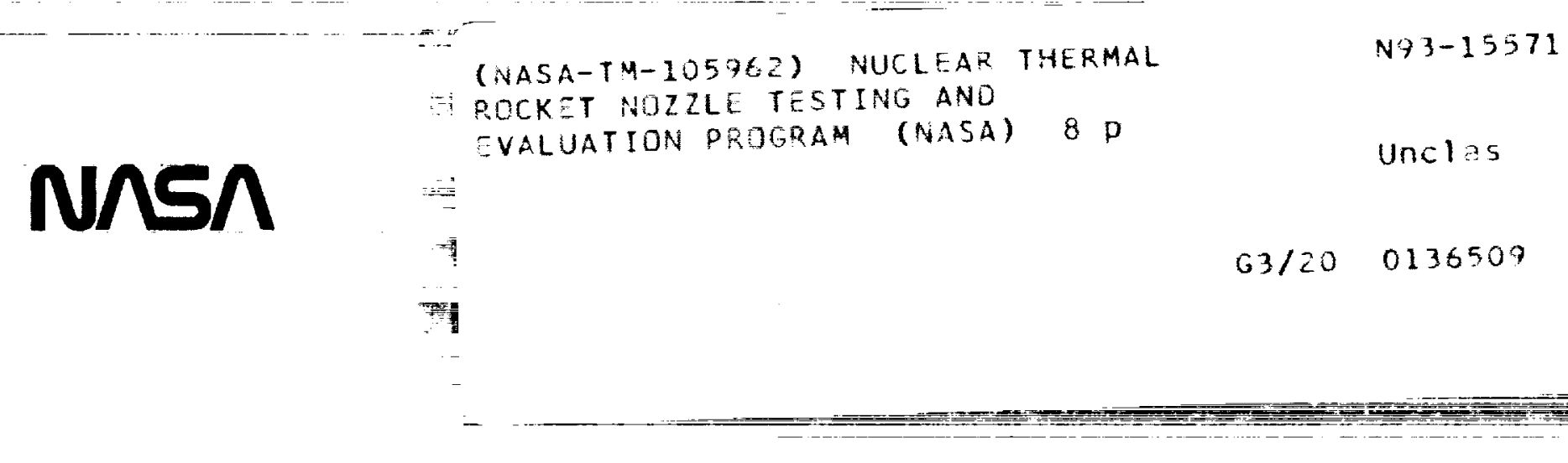


$=$ 


\title{
NUCLEAR THERMAL ROCKET NOZZLE TESTING AND EVALUATION PROGRAM
}

\author{
Kenneth O. Davidian and Kenneth J. Kacynski \\ NASA Lewis Research Center \\ Mail Stop SPTD-4 \\ 21000 Brookpark Road \\ Cleveland, Ohio 44135-3191 \\ (216) $977-7495 /(216) 977-7497$
}

\begin{abstract}
Performance characteristics of the Nuclear Thermal Rocket can be enhanced through the use of unconventional nozzles as part of the propulsion system. In this report, the Nuclear Thermal Rocket nozzle testing and evaluation program being conducted at the NASA Lewis Research Center is outlined and the advantages of a plug nozzle are described. A facility description, experimental designs and schematics are given. Results of pretest performance analyses show that high nozzle performance can be attained despite substantial nozzle length reduction through the use of plug nozzles as compared to a convergent-divergent nozzle. Pretest measurement uncertainty analyses indicate that specific impulse values are expected to be within plus or minus $1.17 \%$.
\end{abstract}

\section{INTRODUCTION}

High performance of a Nuclear Thermal Rocket (NTR), typically achieved through the use of high area ratio $(\varepsilon>$ 100:1) convergent-divergent (C-D) nozzles, can be achieved with a reduction in nozzle length (and weight) by using unconventional nozzles, including single expansion plug nozzles. The NTR nozzle testing and evaluation program being conducted at the NASA Lewis Research Center (LeRC) will experimentally validate existing nozzle performance codes and compare the measured performance of high area ratio C-D nozzles with similar plug nozzles.

Two sets of testing will be performed. The first set will compare the cold flow performance of a low thrust C-D nozzle with a plug nozzle. The second set of testing will measure the hot flow performance of a high thrust 200:1 plug nozzle. In both sets of tests, engine thrust and propellant weight flow will be measured to calculate nozzle specific impulse. Pretest measurement uncertainty analyses have been performed and the results will be compared with posttest analyses. Post-test analysis comparison with actual test conditions will validate the technical codes.

\section{PROGRAM DESCRIPTION}

Demonstration of a simulated Nuclear Thermal Rocket (NTR) will be accomplished at the NASA Lewis Research Center as part of the NTR nozzle testing and evaluation program currently in progress. The program is comprised of two phases: Phase 1 encompasses cold-flow testing, and Phase 2 contains hot flow tests.

Phase 1 is broken into two parts. The objectives of Phase 1-A include validating the computer program which was used as part of this effort to predict the performance of low thrust $\left(445 \mathrm{~N}, 100 \mathrm{lb}_{\mathrm{f}}\right)$, high area ratio, convergentdivergent nozzle rocket engines using room temperature diatomic hydrogen as the working fluid. Phase 1-B will validate the analytic perfomance prediction of a high area ratio plug nozzle rocket engines operating at the same conditions as in Phase 1-A. Comparisons between the plug nozzle performance and C-D nozzle performance will be made.

Phase 2 of experimentation is scheduled to occur approximately one year after the first and will validate the analytic performance prediction of high thrust $\left(22.2 \mathrm{KN}, 5,000 \mathrm{lb}_{\mathrm{f}}\right)$, high area ratio plug nozzle chemical rocket engines using low mixture ratio $(\mathrm{O} / \mathrm{F}=2) \mathrm{H}_{2} / \mathrm{O}_{2}$ combustion products as the working fluid. These operating conditions achieve high temperatures and high flow Reynolds numbers in the range of a full-scale NTR. The low mixture ratio maximizes the amount of hydrogen in the flow to approximate NTR flow conditions as closely as 
possible. Comparisons between plug nozzle and C-D nozzles will be made.

\section{Test Facility}

Testing will be done in the altitude test capsule at the NASA LeRC Rocket Engine Test Facility (RETF). Figure 1 is a schematic diagram of the facility. The water-jacketed second throat diffuser connects the test capsule to the spray cooler. The kinetic energy of the rocket exhaust gases is used in this diffuser to accomplish some of the altitude pumping of the test capsule. The facility is able to provide test-capsule pressures of 206.8 to $344.7 \mathrm{~N} / \mathrm{m}^{2}$ ( 0.03 to 0.05 psia) while exhausting the gas into the spray cooler at pressures of 2068.4 to $4136.9 \mathrm{~N} / \mathrm{m}^{2}$ ( 0.3 to $0.6 \mathrm{psia}$ ). In tests using hydrogen and oxygen propellants (Phase 2), the exhaust gases are removed from the spray cooler by two means. Approximately half of the exhaust gases (product of hydrogen/ oxygen combustion) are condensed to water in the spray cooler. This water, along with the cooling spray

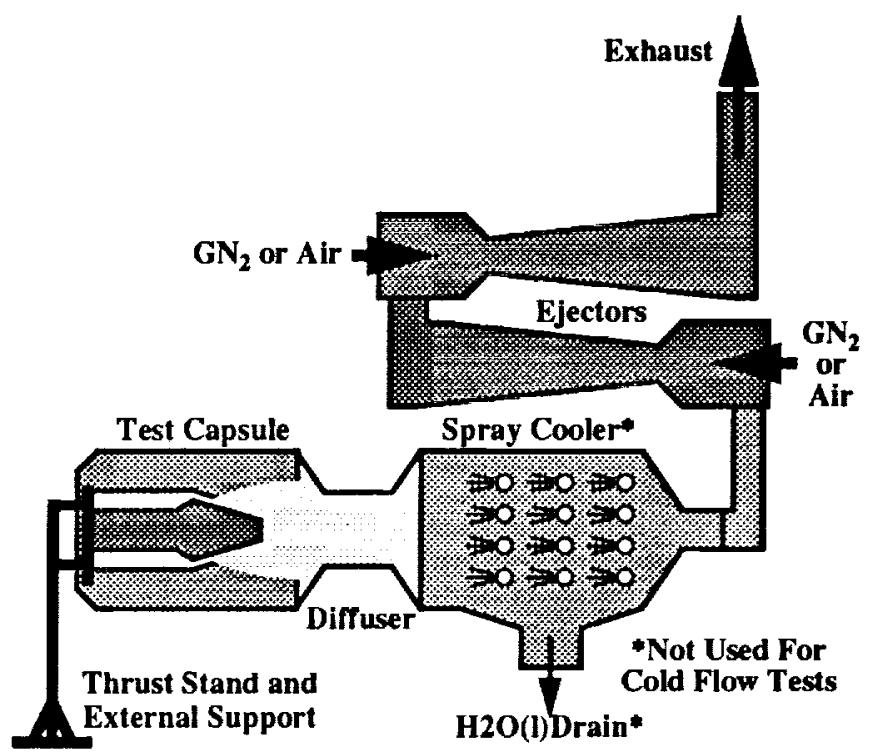

FIGURE 1. Cutaway View of Altitude Test Capsule, Spray Cooler and Ejectors. (Kacynski et. al., 1987) water, exit the spray cooler through a vertical drain line into a cylindrical detention tank. This vertical drain line functions as a barometric leg, allowing water to exit while preventing atmospheric air from entering the spray cooler. The remaining exhaust gases (the noncondensibles) are pumped by the gaseous-nitrogen-driven ejectors shown mounted on top of the spray cooler. Four ejectors, connected in a series-parallel arrangement, provide two trains of two stages each. The exhaust from these ejectors is directed up through two short stacks and vented to the atmosphere. In tests involving only hydrogen (Phase 1), only the ejectors are used to remove the exhaust gases.

The test engine is mounted on the horizontal thrust stand. The thrust stand can measure $13.34 \mathrm{kN}\left(3,000 \mathrm{lb}_{\mathrm{f}}\right)$ of thrust full scale and is attached to a foundation that is separate from the test capsule bulkhead. The thrust structure passes through the test capsule bulk head by means of isolation ports that are sealed by metal bellows and are attached to the concrete outside the test capsule. The thrust stand is designed to have a $2 \sigma$ variation of less than 0.1 percent of full scale thrust. While at altitude the thrust stand can be calibrated remotely against an additional load cell. This

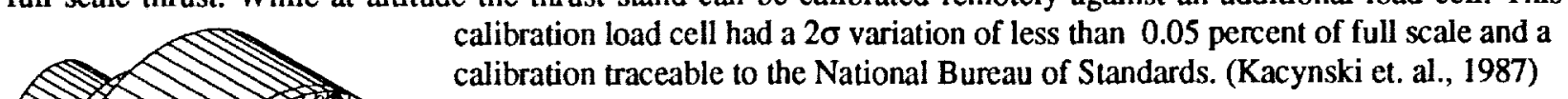

\section{Test Hardware}

Research hardware required for Phase 1-A is a single cold-flow C-D nozzle assembly. For Phase 1-B, multiple cold-flow plug nozzle assemblies (each differing in the amount of truncation) will be necessary. Phase 2 of the program, the hot flow tests, will make use of three cooled or heat sink plug nozzle assemblies. Details of Phase 1-A and Phase 1B hardware are given below.

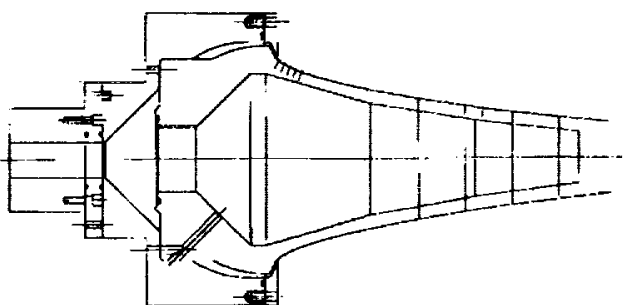

FIGURE 2. Isometric and Schematic Drawing of the Plug Nozzle.
The hydrogen injection apparatus is comprised of flow straighteners, a series of either rigimesh or porous steel plates to mix the hydrogen and a toroidal injection manifold fed by two inlets (to balance axial forces on the engine) through a set of inlet holes which lead to the subsonic chamber. 
A cold flow convergent-divergent nozzle was designed that employs a Rao contour, designed with an area ratio of 200:1.

Cold flow plug nozzles (Figure 2) designed to the same exit Mach number ( $\sim 9.2)$ as the C-D nozzle. The throat section is comprised of 100 two-dimensional channels at the throat with perfect bell contours. Where the twodimensional bell contours end and the plug contour begins, flow conditions (Mach number and flow angle) were matched.

\section{Instrumentation}

The engine instrumentation system for Phase 1-A is displayed in Figure 3 and for Phase 1-B in Figure 4. Hydrogen flow rates are determined using calibrated sonic venturis. Temperatures are measured using Chromel-Constantan thermocouples. A thermocouple type vacuum gauge is used to measure the vacuum reference pressure while the remaining pressures are measured by strain-gauge bridge type pressure transducers. Absolute and differential pressure transducers are used. The thrust stand is capable of measuring thrust levels to $13.3 \mathrm{KN}\left(3000 \mathrm{lb}_{\mathrm{f}}\right)$ and was designed to have a random error of less than $0.1 \%$ of full scale.

Instrumentation in the facility's data acquisition system provides analog signals that are recorded and converted to a digital signal by an automatic data digitizer at a rate of 50 readings per second per parameter. The computer averages the values in groups of five to provide data output at 0.1 second intervals.

Site thrust, the force actually acting on the test stand, is measured by a triad of load cells in a parallel configuration to account for a thrust vector which is not perfectly aligned with the rocket engine's centerline axis. Similarly, other transducers may be shown in Figures 3 and 4 as one device when, in fact, there may be more than one instrument recording data at that location. In these cases, the redundancy was to identify faulty transducers should one fail.

Upstream of the sonic venturi, propellant line pressure and temperature are recorded. Just upstream of the injector, each propellant's pressure and temperature is again measured. Pressure transducers are located in the subsonic chamber and differential transducers between the injector and chamber pressure transducers to allow for direct measurement of injector pressure drop. Redundant measurements of injector pressure drop are also obtained by subtracting the chamber pressure from the injection pressure. Differential pressure transducers, referenced to a vacuum tank, are used to measure nozzle wall static pressure and capsule (ambient) pressure (Kacynski et. al., 1987).

\section{Test Operating Ranges}

Test conditions for the cold flow tests include low chamber pressure (less than $2 \mathrm{MPa}, 300 \mathrm{psia}$ ), low Reynolds number flow, and room temperature $\mathrm{H}_{2}$ gas $(286 \mathrm{~K}, 515 \mathrm{R})$. Limits imposed by the test facility spray cooler and ejectors determined the throat

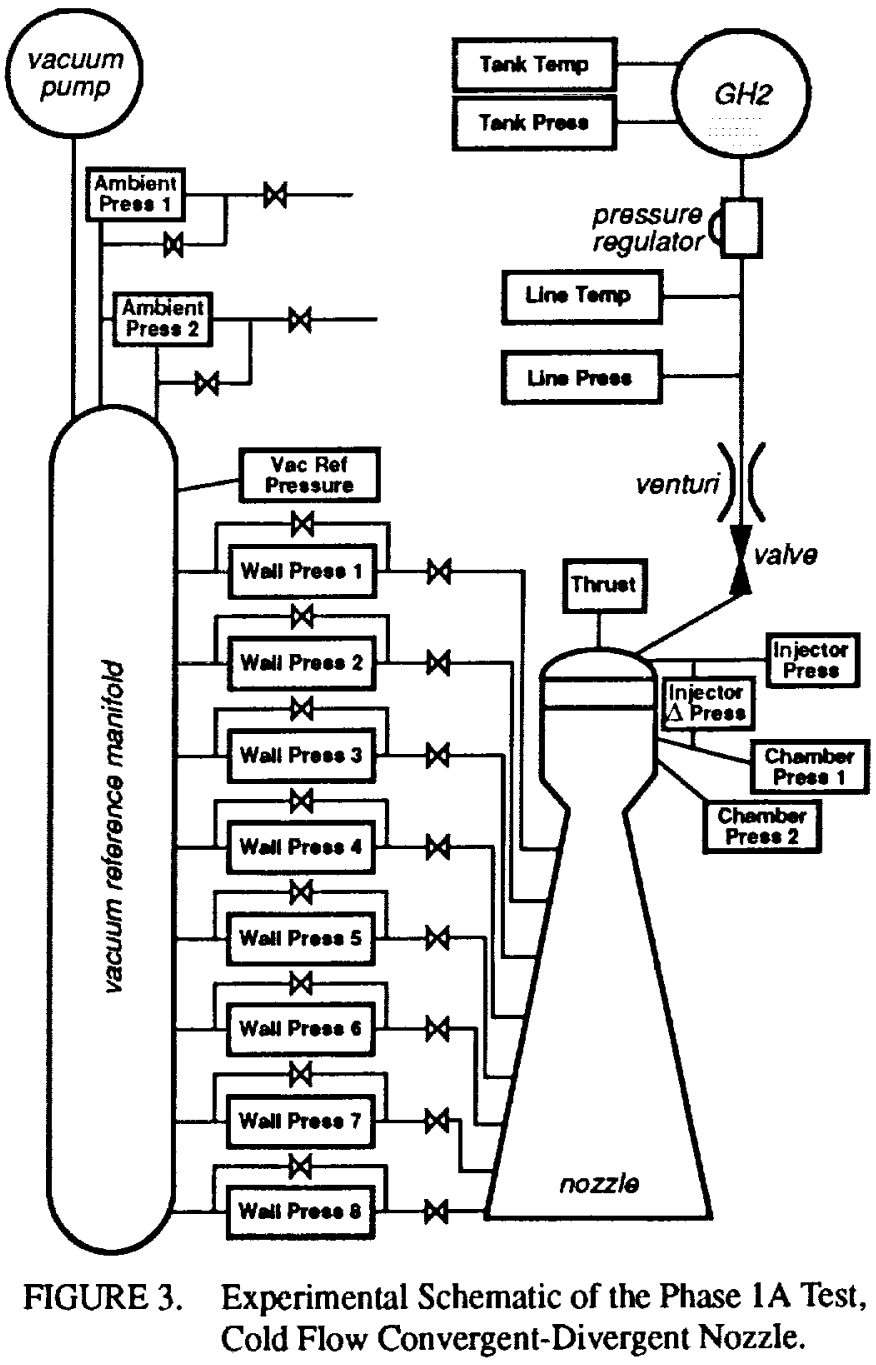




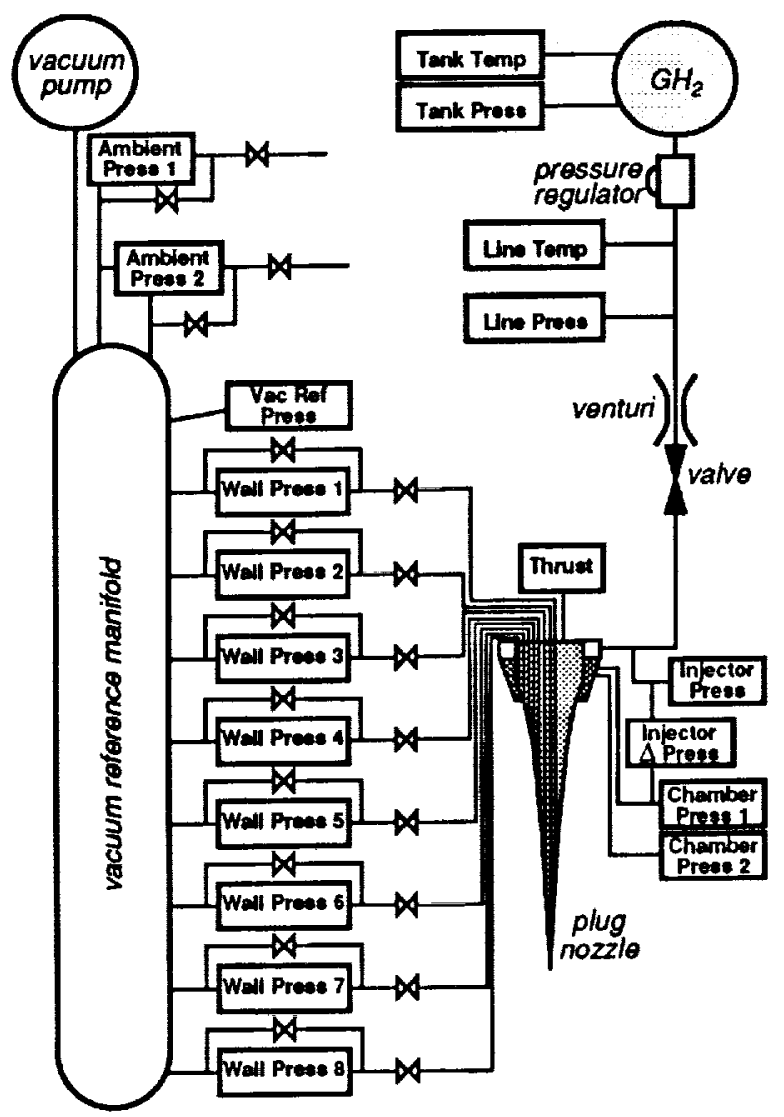

FIGURE 4. Experimental Schematic of the Phase IB Test, Cold Flow Plug Nozzle. diameter and area ratio combination for the test engine.

Test conditions for the hot flow tests, aimed at simulating the NTR hot hydrogen flow field, include midrange to high-range chamber pressure $\cong 3.5$ to $13.8 \mathrm{MPa}$, $\cong 500$ to 2,000 psia), high Reynolds number flow, low mixture ratio $(\mathrm{O} / \mathrm{F}=2) \mathrm{H}_{2} / \mathrm{O}_{2}$ propellants, and high combustion chamber temperatures $(\cong 2,200 \mathrm{~K}, \cong 4,000 \mathrm{R})$.

The proposed test matrix for the cold flow tests (Phases 1-A and 1-B) are given in Table 1. The test matrix for Phase 2 will be determined based on the cold flow test results.

\section{PRETEST ANALYSES}

\section{Performance}

Rocket engine performance predictions for the C-D nozzle were made using the Two-Dimensional Kinetics (TDK) computer code (Nickerson, et. al., 1985). Performance predictions for the plug nozzle were made using the Liquid Propellant Performance (LPP) computer code, a proprietary version of its public domain counterpart, TDK.

A performance prediction summary of the C-D and the plug nozzle is given in Table 2. The purpose of this table is to provide information about the C-D nozzle performance rather than to compare nozzle performance values. Because LPP calculations for the plug start at the exit

plane of the 2-D throat channel, there are no values in Table 2 for the plug nozzles thrust chamber operating conditions or thrust chamber performance. At the point where LPP computations begin, the flow has already partially expanded and inputs to LPP reflected the conditions at that point. One-dimensional performance values, which are calculated based on nozzle area ratio, are not available for the plug nozzle because the definition of the term "area ratio" is not clearly defined when referring to this type of nozzle.

A two-dimensional flow performance comparison between the C-D and the plug nozzles shows that the full-length plug nozzle achieves $98.9 \%$ of the predicted value of the C-D nozzle's specific impulse. However, the real benefits of plug nozzles are maximized when they are shortened in length. Based on previous analysis with a geometric area ratio of 200:1 (O'Brien 1979), plug nozzle performance as measured by vacuum thrust coefficient will decrease by approximately $1 \%$ when the length is truncated to $30 \%$ of full length, and by $1.5 \%$ when truncated to $20 \%$ of full length (Figure 5). Therefore, a plug nozzle which is onefifth as long as a C-D nozzle with the same geometric area ratio is expected to have a (two-dimensional flow) performance of 271.2 seconds, which is $97.4 \%$ (a difference of 7.3 seconds) of the full length convergentdivergent nozzle.

\section{Measurement Uncertainty}

The objective of the uncertainty analysis was to determine the uncertainty on the calculated value of specific impulse from measurements taken during the NTR nozzle testing and evaluation program. A

TABLE 1. Cold Flow (Phase 1) Test Matrix.

\begin{tabular}{ccccc}
\hline $\begin{array}{c}\text { Chamber } \\
\text { Pressure } \\
\text { (MPa) }\end{array}$ & $\begin{array}{c}\text { Chamber } \\
\text { Pressure } \\
\text { (psia) }\end{array}$ & Nozzle & $\begin{array}{c}\text { Length } \\
\text { (\% Full } \\
\text { Length) }\end{array}$ & $\begin{array}{c}\text { \# of } \\
\text { Tests }\end{array}$ \\
\hline $0.34-2.07$ & $50-300$ & C-D & 100 & 6 \\
$0.34-2.07$ & $50-300$ & Plug & 100 & 6 \\
$0.34-2.07$ & $50-300$ & Plug & 25 & 6 \\
$0.34-2.07$ & $50-300$ & Plug & 20 & 6 \\
$0.34-2.07$ & $50-300$ & Plug & 15 & 6 \\
\hline
\end{tabular}


TABLE 2. Convergent-Divergent (C-D) Nozzle (Phase 1A) and Plug Nozzle (Phase 1B) Cold Flow Performance Analyses Summaries.

\begin{tabular}{|c|c|c|}
\hline & C-D & PLUG \\
\hline \multicolumn{3}{|c|}{ Thrust Chamber Operating Conditions } \\
\hline Pressure, MPa (psia) & $0.6895(100.0)$ & $0.6895(100.0)$ \\
\hline Temperature, $\mathrm{K}(\mathrm{R})$ & $285.9(514.7)$ & $285.9(514.7)$ \\
\hline \multicolumn{3}{|c|}{ Exit Plane Flow Properties } \\
\hline Axis Pressure, MPa (psia) & 0. (0.) & $0 .(0)$. \\
\hline Wall Pressure, $\mathrm{Pa}$ (psia) & $85.50(0.0124)$ & $36.54(0.0053)$ \\
\hline Wall Temperature, K (R) & $16.95(30.51)$ & $14.4(25.92)$ \\
\hline Wall Velocity, $\mathrm{m} / \mathrm{s}(\mathrm{ft} / \mathrm{s})$ & $2,701 .(8,862)$. & $2,682 .(8,800)$. \\
\hline Wall Mach Number & 8.341 & 9.190 \\
\hline \multicolumn{3}{|c|}{ One-Dimensional Flow Performance } \\
\hline Specific Impulse, $s$ & 279.1 & Not Computed \\
\hline \multicolumn{3}{|c|}{ Two-Dimensional Inviscid Flow Performance } \\
\hline Thrust, $N\left(\mathrm{lb}_{\mathrm{f}}\right)$ & $432.7(97.27)$ & $340.3(76.51)$ \\
\hline Flow Rate, $\mathrm{kg} / \mathrm{s}\left(\mathrm{lb}_{\mathrm{m}} / \mathrm{s}\right)$ & $.1584(0.3493)$ & $0.1260(0.2777)$ \\
\hline Specific Impulse, $s$ & 278.5 & 275.5 \\
\hline \multicolumn{3}{|c|}{ Two-Dimensional Viscous Flow Performance } \\
\hline Thrust, $\mathbf{N}\left(\mathbf{l b}_{\mathrm{f}}\right)$ & $431.1(96.91)$ & Not Computed \\
\hline Thrust Coefficient & 1.714 & Not Computed \\
\hline Specific Impulse, $s$ & 277.5 & Not Computed \\
\hline
\end{tabular}

and

- All data reduction errors were zero. For this experiment, this assumption is reasonable since the computer truncation errors and high order curve fit errors are negligible.

Table 3 gives a listing of the measured and calculated parameters, the nominal values, the precision error values, the degrees of freedom (V), the uncertainty values and the uncertainty (UNC) expressed as a percentage.

Specific impulse, the performance parameter of greatest interest, is measured with an uncertainty of plus or minus 3.5 seconds, or approximately plus or minus $1.17 \%$. The error component which contributes the most to the specific impulse uncertainty is the calibration error of the site thrust measurement.

\section{CONCLUSIONS}

A two-phase experimental research program is being conducted at the NASA Lewis Research Center to compare performance of a convergentdivergent (C-D) nozzle to a shorter plug nozzle. First phase testing compares the cold-flow performances of a C-D and plug nozzles of similar geometric area ratios. The second phase of tests will demonstrate hot (low mixture ratio, measurement uncertainty for a given parameter means that that parameter value can expect to be within the uncertainty range $99 \%$ of the time. Uncertainties for measured parameters used in the calculation of specific impulse were calculated along with those for other measured and calculated parameters of interest. Employed was the measurement uncertainty methodology for chemical rocket engines which was established by JANNAF (Joint Army Navy NASA Air Force), formerly the Interagency Chemical Rocket Propulsion Group (ICRPG) (Abemethy 1969).

The following assumptions were made in the analysis:

- The experiment for which the uncertainty analysis was performed consists of carefully controlled measurement processes. Calibration corrections for all instrumentation were perfectly carried out. This eliminated large bias ertors of known magnitude. Small bias errors were assumed to be zero. In reality, the bias errors of measuring devices are not zero, although they generally are very small;

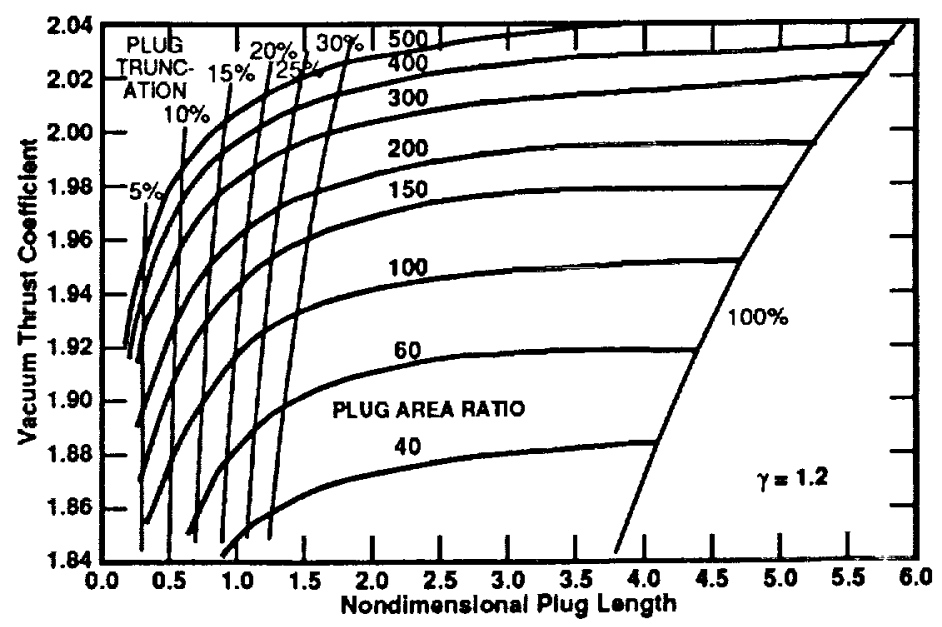

FIGURE 5. Plug Nozzle Two-Dimensional Thrust Coefficient variation with Plug Nozzle Length (from O'Brien 1979). 
TABLE 3. Results of Pretest Uncertainty Analysis

\begin{tabular}{|c|c|c|c|c|c|}
\hline VARIABLE NAMES & $\begin{array}{l}\text { NOMINAL } \\
\text { VALUE }\end{array}$ & $\begin{array}{l}\text { PRECISION } \\
\text { ERROR }\end{array}$ & $v$ & $\begin{array}{l}\text { UNCERTNTY } \\
\text { VALUE }\end{array}$ & $\begin{array}{c}\text { UNC } \\
\%\end{array}$ \\
\hline Line Pressure, MPa (psia) & $2.064(299.3)$ & $0.0089(1.290)$ & 5 & $0.0229(3.316)$ & 1.108 \\
\hline Line Temperature, $\mathrm{K}(\mathrm{R})$ & $296.4(533.6)$ & $0.0434(0.0782)$ & 5 & $0.1117(0.2011)$ & 0.038 \\
\hline Line Diameter, mm (inches) & $3.279(0.1291)$ & 0. (0.) & 6 & $0 .(0)$. & 0.000 \\
\hline Throat Diameter, mm (inches) & $0.8915(0.0351)$ & $0 .(0)$. & 6 & $0 .(0)$. & 0.000 \\
\hline Site Thrust, $N\left(\mathrm{lb}_{\mathrm{f}}\right)$ & $1,314 .(295.4)$ & $7.490(1.684)$ & 30 & $14.98(3.3676)$ & 1.140 \\
\hline Nozzle Exit Area, $m^{2}$ (inches $^{2}$ ) & $0.0734(113.7)$ & $6.45 \mathrm{e}-6(0.0100)$ & 30 & $1.290 \mathrm{e}-5(0.0200)$ & 0.018 \\
\hline Ambient Pressure \#1, Pa (psia) & $225.5(0.0327)$ & $25.90(0.0038)$ & 5 & $66.88(0.0097)$ & 29.500 \\
\hline Ambient Pressure \#2, $\mathrm{Pa}$ (psia) & $273.0(0.0396)$ & $25.90(0.0038)$ & 30 & $51.71(0.0075)$ & 18.964 \\
\hline Average Ambient Pressure, $\mathrm{Pa}$ (psia) & $249.6(0.0362)$ & $25.93(0.0038)$ & 17 & $54.47(0.0079)$ & 21.932 \\
\hline Line Entropy, $\mathrm{kJ} / \mathrm{kg} / \mathrm{K}\left(\mathrm{BTU} / \mathrm{lb}_{\mathrm{m}} / \mathrm{R}\right)$ & $52.10(12.47)$ & $0.0195(0.0047)$ & 5 & $0.0501(0.0120)$ & 0.096 \\
\hline Throat Pressure, MPa (psia) & $1.1045(160.2)$ & $0.0051(0.7448)$ & 5 & $0.0132(1.9149)$ & 1.196 \\
\hline Throat Density, $\mathrm{kg} / \mathrm{m}^{3}\left(\mathrm{lb}_{\mathrm{m}} / \mathrm{ft}^{3}\right)$ & $1.064(0.0664)$ & $0.0049(0.0003)$ & 5 & $0.0128(0.0008)$ & 1.190 \\
\hline Throal $\mathrm{Cp}$ & 3.691 & .0001429 & 6 & 0.0003 & 0.009 \\
\hline Throat $\mathrm{Cv}$ & 2.696 & .0001306 & 5 & 0.0003 & 0.012 \\
\hline Throat Velocity, m/s (ft/s) & $278.5(913.7)$ & $0.0016(0.0054)$ & 5 & $0.0042(0.0138)$ & 0.000 \\
\hline Mass Flow Rate, $\mathrm{kg} / \mathrm{s}\left(\mathrm{lb}_{\mathrm{m}} / \mathrm{s}\right)$ & $0.4541(1.001)$ & 0. (0.) & 5 & 0. (0.) & 0.000 \\
\hline Vacuum Thrust, $N\left(\mathrm{lb}_{\mathrm{f}}\right)$ & 1,332. (299.5) & $1.345(0.3024)$ & 31 & $2.690(0.6047)$ & 0.202 \\
\hline Vacuum Specific Impulse, $s$ & 299.3 & 1.749 & 31 & 3.4976 & 1.169 \\
\hline
\end{tabular}

high Reynolds number) flow performance of a plug nozzle. Both phases will be used to validate anaiytic performance prediction.

Testing will be conducted in the NASA Lewis Rocket Engine Test Facility altitude test capsule. Thrust and mass flow rate will be measured to calculate specific impulse. Pretest analyses of the C-D and plug nozzle performance shows that a full-length plug will give $98.9 \%$ of the performance of a full-length C-D nozzle. By truncating the plug to a length equal to $20 \%$ of the full-length C-D nozzle, the plug nozzle performance decreases to $97.4 \%$ of the C-D nozzle performance. The nozzle length savings, and hence weight savings, may be substantial enough to warrant consideration of a truncated plug nozzle in future propulsion system designs.

Pretest uncertainty analyses indicate measurements will result in the true preformance value to within plus or minus $1.17 \%$. This value may be decreased by decreasing the calibration error of the site thrust load cells. The testing and analsis performed at NASA LeRC for the Nuclear Thermal Rocket program may lead to significant improvements in the design of the propulsion system. In addition, this program provides the basis for future work in the area of chemical propulsion nozzle experimentation.

\section{References}

Abernethy, R. B., et. al. (1969) "ICRPG Handbook for Estimating the Uncertainty in Measurements Made With Liquid Propellant Rocket Engine Systems," CPIA No. 180.

Davidian, K. O., R. H. Dieck, and I. Chuang (1987) "A Detailed Description of the Uncertainty Analysis for High Area Ratio Rocket Nozzle Tests at the NASA Lewis Research Center," NASA TM 100203, NASA Lewis Research Center, Cleveland, OH, October 1987.

Kacynski, K. J., A. J. Pavli, and T. A. Smith (1987) "Experimental Evaluation of Heat Transfer on a 1030:1 Area Ratio Rocket Nozzle,” NASA TP 2726, NASA Lewis Research Center, Cleveland, OH, August 1987.

Nickerson, G. R., L. D. Dang, and D. E. Coats (1985) "Engineering and Programming Manual: Two-Dimensional Kinetic Reference Computer Program (TDK)," NASA CR NAS8-35931, SEA SN-63, Carson City, NV, 1985. O’Brien, C.J. (1979) “Unconventional Nozzle Trade-off Study, Final Report," NASA CR-159520, July 1979. 


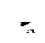


Public reporting burden for this collection of information is estimated to average 1 hour per response, including the time for reviewing instructions, searching existing data sources, gathering and mainfaining the data needed, and completing and reviewing the collection of information. Send comments regarding this burden estimate or any olher aspect of this collection of inlormation, including suggestions for reducing this burden, to Washinglon hent and Budget, Paperwork Reduction Project (0704-0188), Washington, DC 20503.

\begin{tabular}{|l|l|l} 
1. AGENCY USE ONLY (Leave blank) & $\begin{array}{c}\text { 2. AEPORT DATE } \\
\text { January } 1993\end{array}$ & $\begin{array}{c}\text { 3. REPORT TYPE AND DATES COVEAED } \\
\text { Technical Memorandum }\end{array}$
\end{tabular}

\section{TITLE AND SUBTITLE}

Nuclear Thermal Rocket Nozzle Testing and Evaluation Program

\section{AUTHOR(S)}

Kenneth O. Davidian and Kenneth J. Kacynski

\section{PERFORMING ORgANIZATION NAME(S) AND ADDRESS(ES)}

National Aeronautics and Space Administration

Lewis Research Center

Cleveland, Ohio 44135-3191

\section{SPONSORING/MONITORING AGENCY NAMES(S) AND ADDRESS(ES)}

National Aeronautics and Space Administration

Washington, D.C. 20546-0001
WU-506-42-72

8. PERForMING ORGANIZATION REPORT NUMBER

E-7482

10. SPONSORING/MONITORING AGENCY REPORT NUMBER

NASA TM- 105962

\section{SUPPLEMENTARY NOTES}

Prepared for the 10th Symposium on Space Nuclear Power and Propulsion sponsored by the Institute for Space Nuclear Power Studies, Albuquerque, New Mexico, January 10-13, 1993. Kenneth O. Davidian and Kenneth J. Kacynski, NASA Lewis Research Center. Responsible person, Kenneth O. Davidian, (216) 433-7495.

\section{2a. DISTRIBUTION/AVAILABILITY STATEMENT}

12b. DISTRIBUTION CODE

Unclassified - Unlimited

Subject Category 20

\section{ABSTRACT (Maximum 200 words)}

Performance characteristics of the Nuclear Thermal Rocket can be enhanced through the use of unconventional nozzles as part of the propulsion system. In this report, the Nuclear Thermal Rocket nozzle testing and evaluation program being conducted at the NASA Lewis Research Center is outlined and the advantages of a plug nozzlc are described. A facility description, experimental designs and schematics are given. Results of pretest performance analyses show that high nozzle performance can be attained despite substantial nozzle length reduction through the use of plug nozzles as compared to a convergent-divergent nozzle. Pretest measurement uncertainty analyses indicate that specific impulsc values are expected to be within plus or minus 1.17 percent.

14. SUBJECT TERMS

Nuclear thermal rocket; Plug nozzles

17. SECUAITY CLASSIFICATION OF REPORT Unclassified
1B. SECURITY CLASSIFICATION OF THIS PAGE Unclassified
19. SECUAITY CLASSIFICATION OF ABSTRACT Unclassified 